\title{
EXPLORING THE FACTORS THAT INFLUENCE CONSUMER'S PURCHASE OF MOBILE PHONES
}

\author{
Bibi Noraini Mohd Yusuf ${ }^{1 *}$, Lim Lye Hock² ${ }^{2}$ Intan Maizura Abd Rashid ${ }^{3}$, Syahira Saaban ${ }^{4}$, Muhammad Fazlee \\ Sham Abdullah ${ }^{5}$ \\ ${ }^{* 1,2,3,4,5}$ School of Business Innovation \& Technopreneurship, UniMAP
}

\section{*Corresponding Author: -}

\begin{abstract}
: -
Nowadays smart phone has become a new social need and trend especially among the younger age groups, thus generating rapid and vast demand for all mobile phone brands. Interestingly, dealers of smart phones need to understand what factors affect such demand, typical features as well as characteristics of the buyers. The main objective of this study is to understand how price, social influences, relative advantage and brand image affect demand of smart phones in the northern regions of Malaysia, where the State of Perlis has been chosen. The primary data of this study was collected by distributing randomly 120 sets of questionnaires to respondents who live in Perlis. The responses obtained were analyzed by several statistical tools namely frequency distribution, mean, standard deviation analysis, Cronbach's Alpha Reliability test, Person Correlation Coefficient and Linear Regression Analysis, computed by a data software, Package for the Social Science (SPSS) version 17.0. This study revealed that price, social influences, relative advantage and brand image have significant relationships towards demand of smart phones. Detailed discussion of the study objectives, literature review, theories, research limitations, conclusions and finally some recommendations for future research study are given below. It is our hope that the results of the study can help mobile phone companies to have better understanding of the features of the smart phone market, be able to produce quality products and improve their marketing strategies.
\end{abstract}

Keywords: Demand of smart phone, price, social influences, relative advantage and brand image

\section{(ㅇ) $(\$)$}




\section{INTRODUCTION}

Mobile phone is now considered as one of the necessary electrical gadgets in life, because the advancement in information technology allows unlimited and borderless communications between people. Communication is important in order to stay in touch with friends and family members, enabling access to electronic-mails, engaging correspondence between business associates or transacting, creating and closing new business contracts. Thus mobile phone industry plays a very important role in today's borderless world of the internet communications. According to Bridges, Rempel and Griggs (2010), in the United States alone, demand for mobile phones have mushroomed from a 5\% penetration rate worldwide ten years ago, to an estimated $61 \%$ penetration rate in 2008 . The demands for smart phones are driven primarily by their product features and brand names. Ranking or demand for smart phones is based on some important unique features. The more advanced feature and technology of a smart phone is, the higher is the demand from enthusiasts.

Owning the latest version of a smartphone, speaks well of the owner and his/her social status in public, much like putting on a designer's clothing. Furthermore, today's smartphones are designed to be very user friendly, thus allowing even the non-educated individual to own one. There are several brands of smart phones developed and typically, these companies will focus on a wide array of designs to entice consumers, ensuring that these devices operate on their very own platforms and operating systems. Some well-known modern platforms available in the market today include BlackBerry, iPhone, Nokia and Android for mobile application development. Aggressive advertising campaigns followed-up by intensive marketing strategies now form part and parcel of activities by manufacturers to increase sales, profitability and maintain market share. This situation indirectly enables customers to have wider selection of brands according to their budgets. Advertisement is the most effective marketing tool for this industry and everyone can use this method, but there are certain laws, regulations and ethics to be abided by manufacturers. There are various types of advertisement that can be used by manufacturers to advertise their products. Advertising is widely used in this process of personality creation and this follows logically from the fact that personalities are particularly useful for the creation of brand associations (Rajagopal, 2006).

Typically, electronic medias, such as television (TV), is the most effective, productive, influential and appropriate mode of advertisement for smart phones. TV has the ability to convey a message to the user because it has a combination of characteristics, such as sound and motion, by being more accurate and can indirectly influence consumer's social taste. This helps the manufacturer to easily reach target audience. Past research reveals that consumers, when asked about a product they are familiar with and have direct experience of, their choices can be well predicted (Requelme, 2001). In Malaysia, the smart phones industry is growing in exponential numbers because there are now few wireless service providers offering excellent packages and promotions for cell phone users. Overall, both the rural and urban subscribers used their phones occasionally rather than frequently, usages being confined mostly with friends. However, usages by rural subscribers are on a more regular basis with family, friends and neighbours (Sey, 2009).

Figure 1: How often the following people use your mobile phone?

\begin{tabular}{l|l|l|l|l}
\hline Frequency & $\begin{array}{l}\text { Family } \\
(\mathbf{n = 1 1 8})\end{array}$ & $\begin{array}{l}\text { Friends } \\
(\mathbf{n = 1 1 8})\end{array}$ & $\begin{array}{l}\text { Neighbours } \\
(\mathbf{n = 1 1 8})\end{array}$ & $\begin{array}{l}\text { Work } \\
\text { Colleagues } \\
(\mathbf{n = 1 1 8})\end{array}$ \\
\hline Daily & 15.3 & 19.5 & 3.4 & 11.0 \\
Occasionally & 65.2 & 60.2 & 28.0 & 39.0 \\
Never & 19.5 & 20.3 & 68.6 & 50.0 \\
Total & 100.0 & 100.0 & 100.0 & 100.0 \\
\hline
\end{tabular}

Source: Araba Sey, Exploring mobile phone-sharing practices in Ghana (2009)

The frequency on usage of smart phones by people may vary and there are two theories that can be associated with this. The first theory is based on Maslow's "Hierarchy of Needs", a social requirement theory created by Abraham Maslow (1943), which emphasizes human's psychological and interpersonal needs and also economic necessities. In the Maslow's hierarchy of needs, there are at least five basic sets of goals which will be referred to as basic needs (Tikkanen, 2011). The basic needs comprise physiological, safety, love, esteem, and self-actualization (Tikkanen, 2011). When all of the basic needs have been met and usually arising from financial affordability, other social necessities will be considered. Thus, it can be said that there are no limitations to human needs. A need can be prioritized into five different pyramid levels, as established by Maslow, these being:

a. Basic physiological needs

b. Safety from external danger

c. Love, affection and social activity

d. Esteem and self-respect

e. Self-actualization and accomplishment.

Maslow believes that the highest level of needs is self-actualization, which refers to people's aspirations to achieve selffulfilment and realize their potential (Cao, Jiang, Oh, Li, Liao and Chen 2012). If we look at the needs of a mobile phone user, these can be classified in several categories according to the above-mentioned Maslow's theory. In the social category, mobile phone can be used in daily social communication. Swann, (2012) stated that people who are born later in the 20th century are more likely to use telephones for more social reasons. People who are unable to use mobile phones, for example as a result of hearing disability, are categorized as being in the lowest of the social hierarchy. Mobile phone can also be used to prolong relationships and maintain connections between each other, where individuals use to fulfil 
their needs. In an esteem category, mobile phone purchase is not only to fulfil the self needs, rather it is purchased to fulfil the wants of the individual, like purchasing a mobile phone as a symbol of status. In the self-actualization stage, needs are not directly related to using telephones, since telephones do not make people feel as though they are being better people, a characteristic that defines self-actualization (Swann, 2012).

Figure 2: Maslow's Hierarchy of Needs

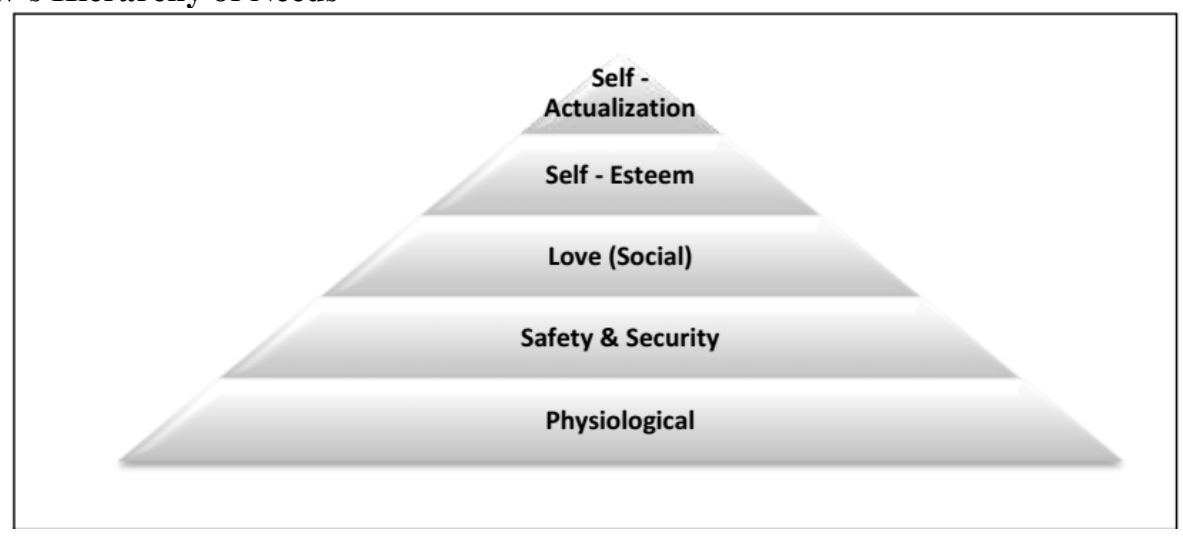

The second theory related to this study is the theory of purchasing. One of past studies on purchasing behaviour in this dominant business sector concluded that many managers in Small and Medium Enterprises (SMEs) do not regard purchasing as a key task and some do not even perceive purchasing as being distinct activity (Ramsay 2008; Ellegard, 2006). There are five marketing steps and decision solving processes in describing purchases by consumers. The solving processes are need, information gathering, evaluating the given alternatives, purchase activity, and also the post purchase status. These five decisions making processes are most suitable for purchases that require problem solving behavior or those involving complex decision-making processes (Saif, Razzaq, Amad and Gul, 2012; Dorsch, Grove and Darden, 2000). The purchase of goods and services performed by user of an offer made by the seller is a simple process involving several decision-making stages (Panatik, Shah and Rajab (2004); Gordon (1994). According to Yang (2010), by providing personal shopping assistant availabilities through the mobile phone, mobile shopping services can transform traditional consumer shopping experiences in brick-and-mortar stores to optimized shopping experiences across channels.

These services can be achievable due to following reasons:

a. by creating real-time interactions between retailers and consumers;

b. by assisting consumers in making smart purchasing decisions by providing customized products/services information; and;

c. by delivering non-intrusive and mobile marketing products to consumers, based on preference and priority.

A purchase process describes how a consumer makes a decision in purchasing a particular product.

Sometimes, the consumer doesn't know why a decision has been made in purchasing that particular phone brand. Factors that influence them to purchase a specific mobile phone are related to vogue, popular among consumers and trendy. According to Requelme, (2001); Newelland Simon, (1972) most marketers assume that customers know and understand what they want. Nevertheless, customers may not know as much as they think they do, ultimately leading to problems in decision making. Trust is very important, according to Ballester and Alleman, (2005), considering brand trust as expectancy, it is based on the consumer's belief that brand has specific qualities that makes it consistent and responsible, contributing to the development of decision making of purchasing mobile phones. We are of the view that, perhaps the reasons proposed in this research, namely brand loyalty, price, quality, social influence or the mobile phone features, could explain the deciding factors for purchase of mobile phones by users.

\section{Research Objectives}

Basically, research objectives state what researchers expect to achieve from the study in general terms. It directly relates to the relative value and usefulness of the output at the end of this study. The objectives of this research are three folds as follows:

a) To determine what factors influence consumers purchasing of mobile phones;

b) To investigate why consumers decide to purchase mobile phones; and

c) To identify what factors influence consumers to purchase mobile phones

\section{Research Questions}

A research question is a clear, focused, brief and in-depth question where the researcher concentrates in the research. The research objectives must address all the research questions so that at the end of the investigation study, the researcher will get valid and valuable results.

a) Does brand loyalty affects consumer's purchasing of mobile phone?

b) Does price affects consumer's purchasing of mobile phone?

c) Does quality affects consumer's purchasing of mobile phone? 
d) Does social influence affects consumer's purchasing of mobile phone?

e) Does mobile phone features affects consumer's purchasing of mobile phone?

\section{Scope of Study}

The research was conducted in the northern region of Malaysia, targeting only the small state of Perlis, Malaysia. This state was chosen because it is the main capital city of Perlis, where many offices and workplaces are found. The respondents chosen were potential customers that had been frequently using mobile phones especially the working groups and furthermore, these groups could afford to buy mobile phones for multiple purposes. This could lead to the accuracy of data obtained and maximize end-results for this research. In this study, the researchers focused on five main independent variables as factors that could influence consumer's purchase of mobile phones. Those variables are brand loyalty, price, quality, social influences and mobile phone features.

\section{Significance of Study}

The importance of undertaking this study is to have wider knowledge horizon about the consumer's brand preference. It is also to investigate consumer's particular brand preference over certain other brands of mobile phones and what factors influence the consumer to make a decision to buy the particular brand. The usefulness of this study is beneficial to mobile phone companies in marketing and advertisement areas.

Consumer's expectations are very high since nowadays the technologies are increasingly advance and the shifting of the environment are different (more on the positive and beneficial to the consumer) every year. Factors influencing mobile phone purchase among consumers can also influence the eventual choice of a particular product. Upon completion of this research and the results obtained, we can know how to assist mobile phone companies to improve their marketing strategies or financing and to focus more about consumer's preference.

\section{LITERATURE REVIEW}

Consumer is defined as a group of people or individual that purchase products and services for personal use. This is because consumer is for the end user. Consumer also can make the ultimate decision of whether to purchase or not to purchase the items sold. They can buy the item at the store or virtually / online. Consumer is also a person who can be influenced by marketing, advertisement and many more. As such, consumers play a vital role in the economic system of a nation. According to Panatik, Shah, Rajab, (2004); Schiffman and Kanuk, (1999), the term consumer is often used to explain the difference between consumer of individual consumer and consumer organizations. Several theories have been developed to describe purchase behaviours among consumers. Although they may vary in form of presentation, most of them are composed of stages such as prepurchase, purchase and post-purchase (Kwok, 2007; Hoyer and Maclnnis, 2001; Rayport and Jaworski, 2003). The final decision to purchase is the most critical and important part in understanding the buying behaviour. According to most researchers, the buying process of online consumers is affected by various factors such as demographic, social, economic, cultural, psychological and other personal factors that are beyond the control and influence of retailers; and marketing stimuli and web experience that can be controlled by marketers (Kwok, 2007; Constantinides, 2004; Kotler, 2003; Jobber, 2001; Boyd et al., 2002).

There is one theory that can define consumer purchase behaviour itself, which is the self-concept theory. For instance, a middle-aged man may view himself as being young for his age group; he may purchase a sports car and a stylish clothing to reflect his self-concept (Boone and Kurtz, 2010). This concept involves two major factors in affecting the buying behaviour of consumers, which are personal and interpersonal. Usually consumer will choose to purchase a product described as being closer to their ideal self-image.

\section{Factors Influencing Mobile Phone Purchase among Consumers}

There are several factors that encourage and explain why consumers buy smart phones, the generic ones being brand loyalty, price, quality, social influence and mobile phone features. The first factor, brand loyalty, shows willingness to pay regardless of a higher price as long as the smart phone is the preferred brand. For example, if a family member usually purchases only 'Sony' brand name in any of their electrical and electronic appliances, naturally there is a high tendency for the whole family members to choose to buy a smart phone of "Sony" brand as well. This is because they have been cultivating brand loyalty all these while, where brand trust is durable in terms of life span, a situation termed as brand loyalty.

According to Tepeci, (1999); Assael, (1991), once customers have made a decision about a brand and its associations, they are often loyal to that brand, will continue to buy it in the future, will recommend it to friends and will choose the product over others, even those with better features or lower prices. In a study conducted by Lin, (2010); Day (1996); Oliver (1999), brand loyalty could be categorized into four parts: cognitive loyalty, affective loyalty, conation loyalty and action loyalty. Subsequently, they also added two other categories for brand loyalty, these being action and affection and divided brand loyalty into true and spurious brand loyalties. This is due to the fact that some consumers do consider purchases as being habitual, selecting a particular brand just because of its prominence in stock and effective promotions (Kwok, 2007; Atilgan et al., 2005; Keller, 1998; Aaker, 1991). The consumer behavior model by a fanatic, Shah, Rajab (2004); Engel et al. al., (1978) placed specific brand as a factor in the evaluation of the said brand. This shows that the brand plays important criteria in the selection process of beliefs and attitudes of consumers.

The second factor is price. Price is usually the first factor that consumer considers before purchasing mobile phones, based on their financial ability. Price also indicates the level of the consumer's income. Some consumers also assume that a high price reflects quality product and likewise low price is for low quality product. According to Swani and Yoo, 
(2010); Bolton, (1989); Foket al., (2006), in consumer's heuristics, a high (low) price connotes a high (low) quality and image. High-priced brands are brands on the market whose image is seen as the key factor. Consumers with high brand loyalty are willing to pay a premium price for their favored brand, so, their purchase intention is not easily affected by price (Yee and Sidek, 2008; Cadogan and Foster, 2000). In addition, customers have strong belief in the price and value of their favorite brands so much so that they would compare and evaluate prices with alternative brands (Evans et al., 1996; Keller, 2003). If the perceived values of the product are greater than cost, it is observed that consumers will purchase that product (Yee and Sidek, 2008). Price has increasingly become a focal point in consumers' judgments of offer value as well as their overall assessment of the retailer (Yee and Sidek, 2008; DeRuyter et al., 1999). According to Bucklin et al. (1998), price significantly influences consumer's choice and incidence of purchase. It has been found that price is more relevant in judging the perceived quality of a product given that a person lacks the technical ability to evaluate the quality of a product (Mokhlis and Yaakop, 2011; Srikatanyoo and Gnoth, 2002; Aaker, 1991; Papadopoulos et al., 1991).

Quality, being the third factor, is very abstract which everybody has his/her own perception and idea about the product quality. It cannot be denied that some customers, being quality conscious, may not necessarily come from higher income groups. The higher the price, the higher is the quality of the product. According to Mosadeghrad (2013), quality has caused company managers throughout the world to consider quality as a strategic goal to achieve competitive advantage over other manufacturers. Kwok (2007); Yasin (2007); Aaker (1991); Keller (1998), Shermen (1992) found that customer has their perception of the overall quality or superiority of a product or service. Lazarova (2010); Steenkamp (1989) identified and developed four major approaches to explaining the concept of quality : (1) the metaphysical approach of philosophy, (2) the production management approach, (3) the economic approach, and (4) the behavioral or perceived quality approach of marketing and consumer behavior. The first approach focuses on the being of quality. The economic approach examines the quality from an economic point of view, such as quality competition, market equilibrium within a situation of product quality variations and consumer behaviour towards products with objective quality variations both when the consumer is perfectly informed and with incomplete knowledge. (Lazarova, 2010).

Social influence, as the fourth factor, could create a big social impact to the consumer in making final decision to purchase mobile phones. In the social hierarchy, people can be grouped as family, friends, relatives, colleagues and so on. These groups sometime act as sales promoters too as they indirectly do promote the products to potential consumers. Going by definition from Wang, et al. (2006), social influence generally refers to processes whereby an individual's beliefs, opinions, attitudes, values, and behaviors are affected by other(s) through social interactions. This more or less helps in the selection by the consumer to purchase the particular products. Another researcher Rashotte, (2006) gave the definition as a change in an individual's thoughts, feelings, attitudes, or behaviors that result from interaction with another individual or a group. Yang, He and Lee, (2007); Hawkins (et al., 1998); Bourne, (1957) and Hyman, (1942) said that social and interpersonal influence research can be traced back to, who first elaborated the term 'reference group', when he asked respondents with which individuals or groups do they compare themselves with. In the business practice, marketers have applied these concepts widely by portraying products being consumed in social situations and inviting prominent/attractive spokespersons to endorse products (Yang, He and Lee, 2007; Chao and Schor, 1998; Beeghley et al., 1990; Bearden and Etzel, 1982; Park and Lessig, 1977; Grubb and Stern, 1971; Hyman and Singer, 1968; Coleman et al., 1966).

Lastly the fifth factor, on mobile phone features, we can easily find mobile phones with wide variety of features. Usually any new technologies applied in any new release of smart phones are the main attraction for new buyers. Salmi and Sharafutdinova, (2008), mentioned that freedom of movement and immediate accessibility have been found to be important benefits specific to mobile communication and in some studies have been recognized as decisive purchasing factor in the choice of this technology. Examples on features of mobile phones are cameras, Bluetooths, Wi-Fis, games, video calls and many more. Mokhlis and Yaakop (2011); Yun, Han, Hong and Kim (2003) had investigated the look-andfeel of fifty different mobile phones using a consumer survey and concluded that phone sizes do play, to some extent, an important role in the decision making purchasing process by consumer. Nevertheless, Karjaluoto et al (2005); Liu (2002) had surveyed Asian mobile phone users and found that sizes of the phones had no significant impact on mobile phone choice, but this finding might be due to the fact that all competing brands have quite similar sized phones that are small enough. Results of studies by Mokhlis and Yaakop (2011); Mack and Sharples (2009) also highlighted the importance of product attributes in predicting choice of mobile phones.

\section{RESEARCH METHODOLOGY}

Researchers have developed suitable theoretical framework to illustrate the relationships between all the variables in this study. The sole dependent variable is the consumer purchasing mobile phones with five independent variables, being factors influencing mobile phone purchase among consumers, these being brand loyalty, price, quality, social influence and mobile features. Based on the objectives of the study, the hypotheses of this study have been designed to find out the significant relationships between the variables or will it lead to the dependent variable of the study. 
The hypotheses are tabulated as follows:

\begin{tabular}{|l|l|}
\hline Hypothesis No. & Hypothesis Statement \\
\hline H1 & Brand Loyalty will lead to consumer purchasing mobile phones \\
\hline H2 & Price will lead to consumer purchasing mobile phones \\
\hline H3 & Quality will lead to consumer purchasing mobile phones. \\
\hline H4 & Social Influence will lead to consumer purchasing mobile phones. \\
\hline H5 & Mobile Features will lead to consumer purchasing mobile phones. \\
\hline
\end{tabular}

These hypotheses were tested using the questionnaires method. Basically, a questionnaire is a set of questions that will be asked by researchers to targeted respondents in order to obtain feedbacks, information and to conduct evaluation for the data analysis. As stated by Saunders, Lewis and Thornhill (2012); deVaus (2002), questionnaire as a general term to include all methods of data collection in which each person is asked to respond to the same set of questions in a predetermined order and ranked by 5-points Likert's Scale. In measuring the response, the Likert's Scale has been applied. The scale denotes certain numbers, ranging from the numbers (1) to (5), where (1) denotes 'Strongly Disagree', (2) denotes 'Disagree', (3) denotes 'Neutral', (4) denotes 'Agree' and lastly (5) denotes 'Strongly Agree'. In computing and analyzing feedbacks from the questionnaires, several statistical tools including the Statistical Programs for Social Science (SPSS) version 17.0 shall be used to analyze the hypotheses and helping the researchers to organize, evaluate and interpret the data. SPSS software also helps to determine the appropriate statistical techniques and tools to be used and to test the hypotheses made by the researchers. A higher percentage of respondents with either "Agree" or "Strongly Agree" respond point will indicate that the specific independent variable has a significant relationship with the dependent variable. In this research, the researchers have chosen to apply the simple random sampling distribution method of questionnaires to respondents, being potential consumers and premised in Perlis area only. The number of respondents targeted was approximately 120 people, coming from a wide spectrum of everyday users, working groups or those with high probability of purchasing new mobile phone models.

\section{FINDINGS}

This part aims to discuss the findings obtained from the questionnaires concerning the research subject; factors influencing consumer purchasing of mobile phones. The aim for this analysis is to find some conclusions to the research objectives. There will be statistical data analysis throughout this chapter. The findings are divided to several sections. First section deals with the demographic profiles of the respondents (age, gender, race, marital status, education level, monthly income and profession). The next second section analyses the reliability of the data computed, measuring the data goodness by using a reliability analysis. This is followed by the third section, which provides the inter-correlation relationships between all variables and descriptive statistics showing the mean and standard deviation of all factors. The fourth section deliberates on the hypotheses testing through a regression analysis. Finally, the last section summarizes the final findings of the research objectives.

\section{Overview of Data Analysis}

Figure 4 shows the sample profile for the survey questionnaires.

\begin{tabular}{|l|l|}
\hline Items & Total Questionnaire \\
\hline Number of questionnaire distributed & $\mathbf{1 2 0}$ \\
\hline Number of questionnaire collected back & $\mathbf{1 0 0}$ \\
\hline Respondent Rate & $\mathbf{8 3 . 3 \%}$ \\
\hline Number of questionnaire used for analysis & $\mathbf{1 0 0}$ \\
\hline
\end{tabular}

Figure 4: Sample Profile

The researchers managed to distribute up to 120 questionnaires; however, only 100 questionnaires were collected back, which made up $83.3 \%$ of total questionnaires received. The questionnaires were found to be satisfactorily completed and tested by using the SPSS software version 17.0. Figure 5 below summarizes all the demographic data of the respondents, ranging from age, gender, race, marital status, education level, monthly income and lastly profession. 
Figure 5: Demographic Characteristics of Respondents

\begin{tabular}{|c|c|c|c|}
\hline Variables & Categories & Frequency & Percentage (\%) \\
\hline \multirow[t]{5}{*}{ Age } & $21-25$ years & 60 & 60.0 \\
\hline & $26-30$ years & 18 & 18.0 \\
\hline & $31-39$ years & 12 & 12.0 \\
\hline & $40-49$ years & 6 & 6.0 \\
\hline & 50 years and above & 4 & 4.0 \\
\hline \multirow[t]{2}{*}{ Gender } & Male & 50 & 50.0 \\
\hline & Female & 50 & 50.0 \\
\hline \multirow[t]{3}{*}{ Race } & Malay & 92 & 92.0 \\
\hline & Chinese & 6 & 6.0 \\
\hline & Others & 2 & 2.0 \\
\hline \multirow[t]{3}{*}{ Marital Status } & Single & 62 & 62.0 \\
\hline & Married & 37 & 37.0 \\
\hline & Widowed / Divorced & 1 & 1.0 \\
\hline \multirow[t]{6}{*}{ Education Level } & SPM & 22 & 22.0 \\
\hline & STPM & 8 & 8.0 \\
\hline & Diploma & 16 & 16.0 \\
\hline & Degree & 50 & 50.0 \\
\hline & Master & 3 & 3.0 \\
\hline & Others & 1 & 1.0 \\
\hline \multirow[t]{6}{*}{ Monthly Income } & RM 1000 and below & 47 & 47.0 \\
\hline & RM $1000-1500$ & 25 & 25.0 \\
\hline & RM $1600-2000$ & 11 & 11.0 \\
\hline & RM $2000-2500$ & 6 & 6.0 \\
\hline & RM $2500-3000$ & 4 & 4.0 \\
\hline & RM 3000 and above & 7 & 7.0 \\
\hline \multirow[t]{4}{*}{ Profession } & Government & 50 & 50.0 \\
\hline & Private & 14 & 14.0 \\
\hline & Students & 35 & 35.0 \\
\hline & Unemployed & 1 & 1.0 \\
\hline
\end{tabular}

Out of 100 respondents, a total of 60 respondents (60\%) were found to be in the 21-25 years age group, with 18 respondents (18\%) to be between the 26-30 years old, 12 of respondents (12\%) aged between 31-39 years, 6 respondents (6\%) aged between 40-49 years and lastly 4 respondents (4\%) aged 50 years and above. In terms of gender, there was an equal distribution, where $50 \%$ of the respondents were male and female each. Malays accounted for majority of the race segment $(92 \%)$, followed by the Chinese $(6 \%)$ and "Others" (2\%). A total of 62 respondents $(62 \%)$ were on single status, 37 respondents $(37 \%)$ were married and only 1 respondent was a divorcee. In respect of higher education, 50 respondents $(50 \%)$ had degree qualifications, 22 respondents $(22 \%)$ attained SPM qualifications, 16 respondents $(16 \%)$ had passed the diploma level, 8 respondents $(8 \%)$ qualified at the STPM level (8\%) and 8 respondents $(8 \%)$ managed to achieve the Masters level. Only 1 respondent $(1 \%)$ had other certification for entry.

In respect of monthly income, $47 \%$ of respondents earned RM 1000 and below, $25 \%$ respondents earned between RM1000 - RM1500, $11 \%$ respondents had monthly income of between RM1500- RM2000, $7 \%$ respondents earned RM3000 and above, $6 \%$ respondents of between RM2000 - RM2500 (6\%) and lastly 9\% of between RM2500 - RM3000. Lastly, as for profession, the majority of respondents (50\%) were working in the government sector, $35 \%$ were students, $14 \%$ were working in the private sectors and finally, only 1 respondent $(1 \%)$ was unemployed.

\section{Reliability Analysis}

Reliability analysis was used to compute and measure the goodness of data and also ensuring that all items used in each variable were free from errors, thus providing consistent results in this research. In this study, the Cronbach's alpha coefficient values for all factors that ranged from 0.662 to 0.837 would indicate good and acceptable inter-item consistency for each factor. Table 6 shows the reliability analysis test results of the variables and the Cronbach's alpha value for each variable. The values computed for the five independent variables were Brand Loyalty (0.788), Price (0.662), Quality (0.795), Social Influence (0.681) and lastly Mobile Features (0.834). Three cut-off values for reliability were established, i.e. Poor (values of 0.600 and below), Acceptable (values of 0.700 and above) and Good (all values above 0.800 ).

Figure 6: Reliability Analysis Test

\begin{tabular}{lllll}
\hline Variables & $\begin{array}{l}\text { Number } \\
\text { Items }\end{array}$ & $\begin{array}{c}\text { of Items } \\
\text { Dropped }\end{array}$ & $\begin{array}{l}\text { Cronbach's } \\
\text { Alpha }\end{array}$ & Indicator \\
\hline Brand Loyalty & 5 & - & 0.788 & Acceptable \\
Price & 5 & - & 0.662 & Acceptable \\
Quality & 5 & - & 0.795 & Acceptable \\
Social Influence & 5 & - & 0.681 & Acceptable \\
Mobile Features & 5 & - & 0.834 & Good \\
\hline
\end{tabular}




\section{Descriptive Analysis among All Variables}

Based on the above table, the mean for all variables computed ranged between 3.4620 to 3.7740 and for the standard deviation, had ranged between 0.70191to 0.84202. The means and standard deviations measurement for the independent variables were Brand Loyalty (3.4620 / 0.70191), Price (3.4620 / 0.70191), Quality (3.6900 / 0.74799), Social Influence (3.4880 / 0.71651) and Mobile Features (3.7740 / 0.83056).

Figure 7: Descriptive Analysis

\begin{tabular}{lll}
\hline \multicolumn{1}{c}{ Factors } & Mean & Standard Deviation \\
\hline Factors influencing consumer purchase of mobile phones & 3.4900 & 0.84202 \\
Brand Loyalty & 3.4620 & 0.70191 \\
Price & 3.4620 & 0.70191 \\
Quality & 3.6900 & 0.74799 \\
Social Influence & 3.4880 & 0.71651 \\
Mobile Features & 3.7740 & 0.83056 \\
\hline
\end{tabular}

Figure 8: Correlation Coefficient Analysis

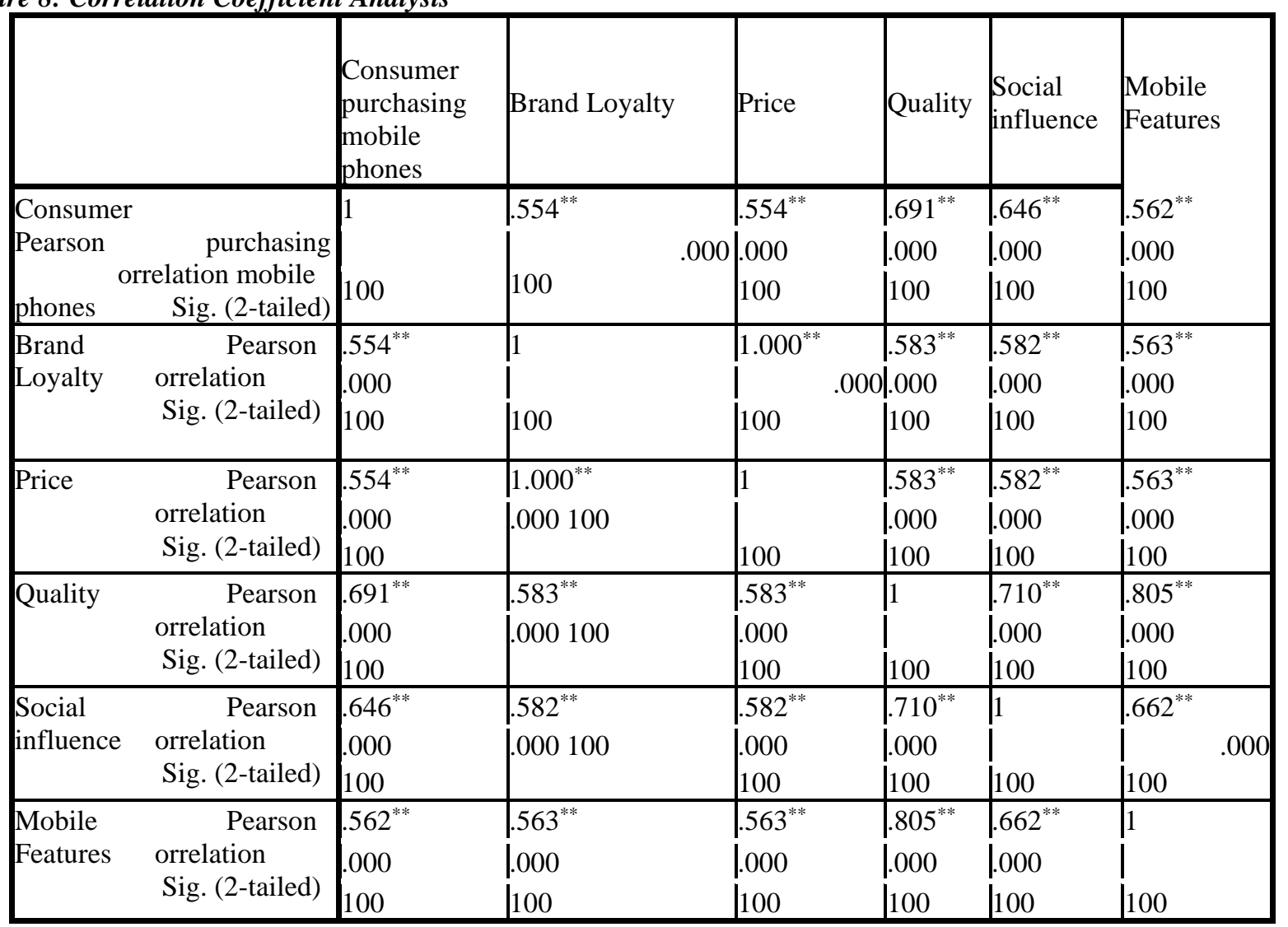

**. Correlation is significant at the 0.01 level (2-tailed).

Figure 8 above shows relationships within the variables, indicating whether each variable has strong correlation with other variables or not. It is noted that Brand Loyalty, Price, Quality, Social Influence and Mobile Features have strongly correlations with the factors influencing mobile phone purchase among consumers with correlation coefficients (Pearson's) of $0.554,0.554,0.691,0.646$ and 0.562 respectively. Any coefficient value approaching 1.000 is interpreted as having a "Strong" relationship. The values of all Pearson correlation in this study were positive, thus indicating positive correlations.

Figure 9: Result of Regression Analysis on Acceptance

\begin{tabular}{llll}
\hline & Beta & t-ratio & Sig. \\
\hline Brand Loyalty & 0.554 & 6.596 & 0.000 \\
Price & 0.174 & 1.938 & 0.056 \\
Quality & 0.776 & 3.701 & 0.000 \\
Social Influence & 0.273 & 2.615 & 0.010 \\
Mobile Features & -100 & -0.826 & 0.411 \\
\hline
\end{tabular}

R square $=.545$

Durbin - Watson $=1.970$ 
Figure 9 tabulates the results of the regression analysis on acceptance. Regression analysis is used to establish the relationships between dependent and independent variables and helps to understand the whether the value of the dependent variable is affected by any change in the value of the independent variables. Research findings indicated that $54 \%$ of the factors influencing purchase of mobile phone among consumers were affected by Brand Loyalty, Price, Quality, Social Influence and Mobile Features, with the remaining $45.5 \%$ affected by other factors. Based on the result above and in order to determine the factors influencing mobile phone purchase by consumers, all the five independent variables must demonstrate significant effects of not more than 0.005 (threshold value), otherwise, the hypothesis has to be rejected.

Hypothesis H1, showed a significant relationship value of 0.000 , between Brand Loyalty and consumer purchasing mobile phones and being less than the threshold value, could be accepted. Price, as in hypothesis $\mathrm{H} 2$, showed a significant relationship value of 0.5 and so has to be rejected. Hypothesis H3, on Quality, showed a significant relationship value of 0.000 , therefore the hypothesis could be accepted. Next, on Social Influence, H4, showed a significant relationship towards the independent variable of 0.010 and could be accepted. Finally, H5 on Mobile Features, showed a high significant relationship value of 0.411 and being above the threshold value of 0.005 , has to be rejected. Based on the analysis that has deliberated above and post-study comments, summarised below are the outcome of the investigations conducted on the five hypotheses established (Figure 10).

Figure 10: Hypothesis Testing Results
\begin{tabular}{lll} 
Hypothesis & Statement of Hypothesis & Results \\
No. & Brand Loyalty will lead to the consumer purchasing mobile phones & Accepted \\
\hline H1 & Price will lead to the consumer purchasing mobile phones & Rejected \\
H3 & Quality will lead to consumer purchasing mobile phones & Accepted \\
H4 & Social Influence will lead to consumer purchasing mobile phones & Accepted \\
H5 & Mobile Features will lead to consumer purchasing mobile phones & Rejected \\
\hline
\end{tabular}

\section{CONCLUSIONS AND RECOMMENDATION}

Findings of the study shall be presented below and few conclusions drawn. Implications of the study coupled with certain qualifications or research limitations shall be stated. Some suggestion(s) for further research shall be outlined, which concludes this research study. The present study was conducted with the main objectives of examining the factors influencing consumer's purchase of mobile phones. The dependent variable established in the research objective was "Consumer purchasing mobile phones" and five independent variables were developed and subsequently tested using several well established statistical measurement tools. Different people have varied preference in purchasing anything. In this case mobile phone has been chosen as subject of the research (the dependent variable). The decision to purchase is sometimes driven by the basic needs and wants of any human being as life escalates to higher and better echelon each day. The data that the researchers captured from the study has been briefly presented, covering a total of 100 feedbacks received (83.3\% response rate). The study shows that only three out the five independent variables established (Brand Loyalty, Quality and Social Influence) are positively related to the dependent variable, while another two variables (Price and Mobile Features) are not the factors that influence consumers purchasing of mobile phones.

Hypothesis 1 (H-1) examined the relationship between "Brand Loyalty" that will lead to consumer purchasing mobile phones. Any customer, who has already put his/her trust in one particular brand name, will likely continue buying the same brand for the next purchase. This is called loyalty towards the brand. Being well accustomed to that brand, the customer will find it difficult to turn over to other brand for their satisfaction towards mobile phone. Under the influence of brand loyalty, consumer will continue to buy the brand, regardless of the superior features, prices and convenience offered by its competitors. The more loyal the consumers are towards the brand, the less vulnerable the customer base would be. (Kwok, 2007; Atilgan et al, 2005; Keller, 1998; Aaker, 1991). This hypothesis, after meeting all the threshold tests, has been accepted.

Hypothesis H-2 examined the relationship between "Price" that will lead to consumer purchasing mobile phones. Price, which comes hand in hand with brand, is also considered having a strong relationship with brand. Consumers with high brand loyalty are willing to pay a premium price for their favoured brand, thus, their purchase intention is not easily affected by price (Yee and Sidek, 2008). However on the contrary, this study results showed otherwise and thus this hypothesis has been rejected.

"Quality" was tested under hypothesis H-3. Some consumer believes that quality can help them to decide whether to buy or not to buy the product. At times, quality is described as exceeding the customer's expectations and the extent to which the customers or users believe the product or service surpasses their needs and expectations. Product quality in a broad sense is defined as "superiority or excellence" of a product (Alfred, 2013; Zeithaml and Dawar; 1999). Results showed that this hypothesis can be accepted, concurring with past researchers.

Next, hypothesis H-4 examined the relationship between "Social Influence" that will lead to consumer purchasing mobile phones. Our environment plays a big role in our daily life. Social influence comes in the form of people (family members, colleagues and friends) and also in the form of environment, such as working place, social place for gathering and so on. 
Besides family, friends and relatives, there are also some other social influences that can be categorized too that can affect purchasing decision, such as some inner thoughts (feelings and attitudes), that can influence the consumer to purchase a mobile phone product. This hypothesis passed the tests and thus H-4 has been accepted.

The last hypothesis, H-5 was about the relationship between "Mobile Features" that will lead to consumer purchasing mobile phones. Mokhlis and Yaakop (2011); Yun, Han, Hong and Kim (2003), had investigated the looks-and-feels of fifty different mobile phones using a consumer survey, where a total of seventy-eight (78) participants had evaluated the design of phones on the perceived scale of "image / impression" characteristics and "overall satisfaction". It was found that "image and impression" characteristics of the products were closely related to the human-product interface specifications as well as overall shape of the product. However, according to this study result, hypothesis H-5 did not meet the criteria established and therefore has been rejected. It can be concluded that not all people (especially respondents in Kangar) will purchase mobile phones based on the features.

The results of the present study shows the importance of knowing what factors that could and possibly would continue to influence any purchase of mobile phones, either from the consumers or manufacturers viewpoints. This study should greatly assist mobile phone companies in understanding the tastes of present and future markets, thus helping manufacturers to develop appropriate marketing strategies and advertising campaigns to promote their products, especially within the research parameter (to the people in Kangar, Perlis). They would understand which target market segment they should focus on, ensuring quality products offerings and how to promote the products, based on the results analyzed from this study. In terms of research limitations, the results of the findings could be biased since the data obtained may not be a total representative of change that occurred in Kangar, given that only 100 respondents (83.3\%) replied to the survey questionnaires. In addition, the geographical distribution of respondents were limited and confined to a small non-densely populated area in Kangar, Perlis, which obviously was not a true representation of the state or a true country wide Malaysian population profile.

On future research recommendations, the researchers trust that all the above-mentioned limitations could be addressed or overcome, thus ensuring a higher degree of reliability with minimum errors. Future studies should take into account wider geographical distributions of respondents, as well as covering larger population size and sampling (higher number of respondents) across states wise and lastly to have varied category such as including urban and rural population as well. Having undertaken and completing this study, the researchers have also enabled academicians, as well as providing useful tips to mobile phone manufacturers, to have a better understanding in knowing the factors that drive a consumer to purchase that particular brand of mobile phones over some other brands, at present and in future.

\section{REFERENCES}

[1].Alfred O., 2013, Influences of Price And Quality on Consumer Purchase Of Mobile Phone In The Kumasi Metropolis In Ghana A Comparative Study, European Journal of Business Management, Vol. 5, No 1

[2].Araba Sey, 2009, Exploring mobile phone-sharing practices in Ghana, Emerald Group Publishing Limited, ISSN 1463-6697 VOL. 11 NO. 2 2009, pp. 66-78,

[3].Ballester E. D., Aleman L, M., 2005, Does Brand Trust Matter To Brand Equity?, Journal of Product and Brand Management, Vol 14, No. 3, pp. 187-196

[4].Boone, L.E.,\& Kurtz, D.L. (2010). Contemporary business (14 $4^{\text {th }}$ ed). Hoboken, New Jersey: John Wiley \& Sons, Inc.

[5].Bridges L, Rempel H. G, Griggs K., 2010,"Making the case for a fully mobile library web site: from floor maps to the catalog", Reference Services Review, Vol. 38 Iss: 2 pp. 309 - 320

[6].Bucklin R. E., Gupta S. and Siddarth S., 1998 Determining Segmentation in Sales Response Across Consumer Purchase Behaviors, Journal of Marketing Research, Vol 35, pp 189-198.

[7].Evans, M., Moutinho, L. and Raaij, W. F. V. (1996), Applied Consumer Behavior. Addison- Wesley: Harlow.

[8].Hernan Riquelme (2001), Do consumers know what they want? Journal of Consumer Marketing, VOL. 18 NO. 5 2001, pp. 437-448.

[9].Huanhuan Cao, Jinhu Jiang, Lih-Bin Oh, Hao Li, Xiuwu Liao and Zhiwu Chen (2012), A Maslow's hierarchy of needs analysis of social networking services continuance, Journal of Service Management Vol. 24 No. 2, 2013 pp. 170-190

[10]. Irma Tikkanen (2011), Nutritionally balanced school meal model for a comprehensive school, British Food Journal Vol. 113 No. 2, 2011 pp. 222-233

[11]. John Ramsay (2008), Purchasing theory and practice: an agenda for change, European Business Review Vol. 20 No. 6, 2008 pp. 567-569.

[12]. Karjaluoto H., Karvonen J., Kesti M., Koivumaki T., Manninen M., Pakola J., Ristola A., Salo J. 2005, Factors

[13]. Affecting Consumer Choice of Mobile Phones: Two Studies from Finland, Journal of Euro marketing Vol 14, pp. 24

[14]. Kwok K. T. 2007, Effect of Brand Image on Consumer Purchasing Behaviour on Clothing: Comparison between China and the UK's Consumers, MSc International Business, pp. 96

[15]. Lazarova R. 2010, Consumer's Perception of Food Quality and Its Relation to the Choice of Food, Master of

[16]. Science in Marketing, Department of Marketing And Statistics, Aarhus Universitet, pp. 86

[17]. Lin L.Y., 2010, The Relationship of Consumer Personality Trait, Brand Personality and Brand Loyalty: An Empirical Study of Toys and Video Games Buyers, Journal of Product and Brand Management, Vol 19/1, pp 4-17.

[18]. Mokhlis S., Yaakop A. 2011, Consumer Choice Criteria in Mobile Phone Selection: An Investigation of Malaysian University Students, International Review of Social Science and Humanities, Vol 2, No. 2, pp. 203-212

[19]. Mosadeghrad A. M., 2013, Healthcare Service Quality: Towards a Broad Definition. Journal of Healthcare Quality Assurance, Vol. 26(3), pp. 203-219 
[20]. Panatik. S. A., Shah I. M., Rajab A. 2004, An Investigation Of Decision-Making Process In Consumers’ Purchasing Behavior: Case Study At Johor Bahru, Jabatan Pembangunan Sumber Manusia, Fakulti Pengurusan Sumber Manusia, Universiti Teknologi Mara, pp. 81. Rashotte, L., 2006, Social Influence, January, pp. 4.

[21]. Rajagopal, 2006, Insights from research Brand excellence: measuring the impact of advertising and brand personality on buying decisions, Emerald Journal, VOL. 10 NO. 3 2006, pp. 56-65, $Q$ Emerald Group Publishing Limited, ISSN 1368-3047.

[22]. Requelme H., 2001, Do Consumers Know What They Want?, Journal of Consumer Marketing, Vol. 18(5), pp. 437448

[23]. Saif N., Razzaq N., Amad A. Gul S. 2012, Factors Affecting Consumers; Choice of Mobile Phone Selection in Pakistan, European Journal of Business and Management, Vol 4. No. 12, pp. 12.

[24]. Salmi A., Sharafutdinova E., (2008) Culture and Design in Emerging Markets: The Case of Mobile Phones in Russia, Journal of Product \& Brand Management, Vol 15. No. 7, pp. 442-449

[25]. Saunders M., Lewis P., Thornhill A. (2012) Research Methods for Business Students (6 ${ }^{\text {th }}$ ed.) United States: Pearson

[26]. Swani K., Yoo B., 2010, Interaction between price and price deal, Journal of Product and Brand Management, Vol $19 / 2$, pp 143-152

[27]. Swann M. 2012, The Application of Maslow's Hierarchy of Needs to College Student Cell Phone Use, Int. Central Michigan, pp. 17

[28]. Tepeci M., 1999, Increasing Brand Loyalty in the Hospital Industry, International Journal of Contemporary Hospitality Management, Vol 11/5, pp 223-229.

[29]. Wang L., Doucet L., Northcraft G., 2006, Culture, Affect, and Social Influence in Decision-Making Groups, Research on Managing Groups and Teams, Vol 9, pp 147-172

[30]. Yang J., He X., Lee H., 2007, Social Reference Group Influence On Mobile Phone Purchasing Behaviour: A CrossNation Comparative Study, Int. Journal Mobile Communication, Vol 5, No 3, pp. 20

[31]. Yee W. F., Sidek Y., 2008, Influence of Brand Loyalty on Consumer Sportswear, Int. Journal of Economics and Management, Department of Management, Faculty of Economics and Management, Universiti Putra Malaysia 2(2), 221-236 pp. 16 